\title{
The effect on sepsis rates of closing and cleaning hospital wards
}

\author{
PAUL NOONE' AND ROSE J. GRIFFITHS \\ From the Department of Microbiology, Central Middlesex Hospital, London
}

SYNOPSIS Sepsis rates were studied in five hospital wards before and after closure for cleaning. Each ward was closed because of an outbreak of Staph. aureus infection caused by a cloxacillinresistant strain.

The study shows that sepsis rates, especially sepsis caused by hospital strains of Staph. aureus, were greatly reduced in the three-month period following re-opening of the ward, provided that patients infected with such organisms were not readmitted to or allowed to remain in the ward.

In some hospitals it is an accepted practice to close and clean hospital wards when outbreaks of staphylococcal and streptococcal sepsis occur, but little has been published about the effect of this practice on the incidence of sepsis. In the past, wards were not often closed in this hospital when sepsis was prevalent, nor has it been a routine practice to close wards at regular intervals for cleaning. In general, wards were closed only for major alterations and/or redecoration. In this paper the effect on sepsis rates of closing and cleaning wards is described.

\section{Methods}

Routine surveillance of all inpatients for sepsis in this hospital was carried out by the Infection Control Sister in cooperation with medical and nursing staff on the wards. Swabs and other samples taken from septic wounds and lesions are submitted to the microbiology laboratory for investigation. All isolations of pathogenic bacteria are recorded and a note is made of those associated with sepsis, together with details of the patient, the site of infection, and the ward. Each isolation from any site, associated with sepsis, caused by a single strain of an organism, is counted as a case of sepsis. Repeated isolations of the same strain from the same site are excluded from the calculations of sepsis rates; only cases of definite sepsis are counted and isolations of potential pathogens colonizing a patient without causing sepsis are also excluded.

Strains of Staphylococcus aureus resistant to tetra-

'Present address: Bacteriology Department, School of Pathology, Middlesex Hospital Medical School, London W1.

Received for publication 10 February 1971. cycline are assumed to be 'hospital strains' (Parker and Hewitt, 1970). In this connexion it is worth emphasizing that, in our experience, multiple antibiotic-resistant strains (including cloxacillin-resistant strains) of Staph. aureus have been isolated only from hospital inpatients or from outpatients known to have become infected while in hospital.

Strains of staphylococci which coagulated plasma broth within four hours, on incubation in a water bath at $37^{\circ} \mathrm{C}$, were regarded as Staph. aureus. Antibiotic sensitivities for Staph. aureus were tested on DST agar (Oxoid) at $30^{\circ} \mathrm{C}$ with Oxoid Multodiscs. Routine testing was carried out with penicillin $(1 \cdot 5 \mu \mathrm{g})$, tetracycline $(10 \mu \mathrm{g})$, erythromycin $(10 \mu \mathrm{g})$, methicillin $(10 \mu \mathrm{g})$, fusidic acid $(10 \mu \mathrm{g})$, lincomycin $(2 \mu \mathrm{g})$, neomycin $(10 \mu \mathrm{g})$, and gentamicin $(10 \mu \mathrm{g})$. After overnight incubation zone sizes were compared with those produced by a strain of Oxford Staph. aureus (NCTC 6571) tested under similar conditions. Test strains of Staph. aureus which grew to within $1 \mathrm{~mm}$ of the methicillin disc under these conditions were considered to be resistant (Hewitt and Parker, 1968). Phage typing of selected isolates was carried out at the Cross Infection Reference Laboratory, Colindale, where further tests for methicillin resistance were also done. The minimum inhibitory concentration (MIC) of methicillin for each resistant strain of Staph. aureus was in excess of $12.5 \mu \mathrm{g} / \mathrm{ml}$. Although methicillin sensitivity is tested in the laboratory, cloxacillin sensitivity is reported to the clinicians, as this is the variety of penicillinaseresistant penicillin most used.

\section{Cleaning of Wards}

After the wards in question had been closed to 
admissions and emptied of patients, all fabrics were sent for laundering and items issued by the Central Sterile Supply Department were returned for reprocessing. Disposable stocks of syringes, blood sample containers, unused swabs, etc, were removed; drug containers were returned to the pharmacy and disinfected.

The cleaning of wards included adjacent offices and side-rooms and involved washing floors, walls, and all other surfaces with hot water containing detergent. Bed frames and furniture were also washed. The cleaning was supervised by the Infection Control Sister and the ward sister concerned.

All staff and patients from the wards were screened for nasal carriage of epidemic strains of Staph. aureus; carriers were treated with $2 \%$ hexachlorophane soap and nasal cream (Noone, Griffiths, and Taylor, 1970). When appropriate, patients were isolated and were not readmitted to cleaned wards until shown to be free from infection or carriage (with the exception of ward 4 see below).

\section{Outbreaks of Sepsis}

Each of the five wards studied was closed for cleaning following an outbreak of sepsis, usually caused by a cloxacillin-resistant strain of Staph. aureus. Four of the wards were surgical and the fifth was a gastroenterological ward containing both medical and surgical patients.

None of the wards studied had isolation facilities apart from one single-bed cubicle and a two-bed side-room. Apart from ward 2 there were no separate rooms for dressing wounds which, therefore, had to be dressed on the main ward.

\section{WAR D 1}

This is a gynaecological ward. The outbreak of sepsis began with an old lady suffering from carcinoma of the vulva. Following an operation for removal of the carcinoma her wound became infected with a cloxacillin-resistant Staph. aureus (phage type RTD 29/42E/47/54/83/84/81): this organism was resistant also to benzyl penicillin, tetracycline, and erythromycin. This patient remained in a side-room of the ward until she died: at necropsy Staph. aureus of the same phage type and with the same resistance pattern to that described was recovered from heart blood and from a spleen swab. Six more patients on the ward became infected with the same organism within the next 10 days, urinary tracts and surgical wounds being chiefly involved. Two nurses were shown to be nasal carriers of this strain, while a further isolation was made from the uniform of another nurse. In view of continuing sepsis the ward was closed for cleaning and redecoration.

WARD 2

This is a neurosurgical ward. The ward was closed when there was an outbreak of Staph. aureus sepsis caused by a strain resistant to cloxacillin and to benzylpenicillin, tetracycline, erythromycin, lincomycin, and chloramphenicol. This strain (phage type RTD 53/75/77/85) was first isolated from a patient who developed a scalp wound infection with a heavy purulent discharge following intracranial surgery for trauma. Further isolations of strains of the same phage type and antibiotic resistance pattern were made from other patients in the ward, including one from the upper respiratory tract of a young man with an open fracture of the skull and cerebrospinal fluid rhinorrhoea, and one from the cerebrospinal fluid of a patient who developed meningoencephalitis following an emergency ventricular tap which was carried out on the ward for raised intracranial pressure. The same organism was isolated at necropsy from this patient's brain.

\section{WAR D 3}

This is a gastroenterological ward for acutely ill female medical and surgical patients. The outbreak of sepsis which led to closure of this ward was caused by Staph. aureus (phage type RTD 42E/47/53/54/75/ 81) resistant to cloxacillin, benzylpenicillin, and tetracycline, but sensitive to erythromycin. Of three patients who developed bronchopneumonia caused by this strain, two died.

WARD 4

This is an acute general surgical ward for female patients. Before closure there was a steady background of sepsis caused by a variety of organisms infecting wounds and respiratory and urinary tracts. There were four cases of sepsis caused by Staph. aureus (phage type RTD 29/6/42E/47/53/54/83A/ $84 / 81$ ) resistant to cloxacillin, benzylpenicillin, tetracycline, and erythromycin which resulted in closure of the ward.

WARD 5

This is an acute general surgical ward for male patients. Before closure of the ward there were five cases of sepsis caused by Staph. aureus (phage type RTD 29/53/83A/84) resistant to cloxacillin, benzylpenicillin, tetracycline, and erythromycin.

In the six months following closure and cleaning of the ward there were three cases of sepsis caused by Staph. aureus resistant to cloxacillin, benzylpenicillin, tetracycline, erythromycin, lincomycin, and chloramphenicol (phage type RTD 53/75/77/85).

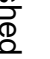

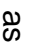
,

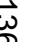


This strain was similar to that which caused the outbreak of sepsis on ward 2. Two of the patients on ward 5 who became infected with this organism were operated on in the same theatre as the infected patients from ward 2 within two weeks of one another. Four other patients, each from a different ward (and not included in this study), and each under the care of a different surgeon or physician, also became infected with a similar strain of Staph. aureus. The only connexion between these patients was that they underwent operation in the same theatre within a period of a few weeks of one another. Carriers of the relevant strain were not found among theatre, medical, nursing or surgical staff, although some members of staff had left the hospital before investigations were made.

\section{Results}

The results are summarized in Tables I and II.

\section{ANTIMICROBIAL THERAPY}

Thirty-four patients on the five wards studied had infections with cloxacillin-resistant strains of Staph. aureus. Twenty-eight were already receiving antimicrobial therapy at the time they became infected.
Twenty-one were receiving some form of penicillin therapy: nine ampicillin; four ampicillin and cloxacillin; one cloxacillin alone; four benzylpenicillin and streptomycin; three benzylpenicillin and sulphadiazine; five patients were receiving tetracycline; one patient trimethoprim-sulphamethoxazole and one patient streptomycin, isoniazid and para-amino salicylate for a tuberculous breast abscess which became secondarily infected with a cloxacillin-resistant Staph. aureus. Each patient receiving cloxacillin, either alone or in combination with ampicillin, was being given $500 \mathrm{mg}$ four times in 24 hours.

The treatment the patients received, once infection with cloxacillin-resistant Staph. aureus was confirmed, varied considerably. Three patients were in a terminal stage of carcinomatosis and received no antimicrobial treatment; one patient died before antimicrobial therapy could be changed to an appropriate course. Nineteen patients received no systemic antimicrobial therapy. In general inappropriate systemic antimicrobial agents were withdrawn where they were already being administered and local treatment with $2 \%$ hexachlorophane cream or wound powder was undertaken. None of these patients died.

\begin{tabular}{|c|c|c|c|c|c|c|c|}
\hline Ward & $\begin{array}{l}\text { Period of Time } \\
\text { in Relation to } \\
\text { Closure }\end{array}$ & $\begin{array}{l}\text { Total Isolations of } \\
\text { Staph. aureus } \\
\text { Associated with } \\
\text { Sepsis }\end{array}$ & $\begin{array}{l}\text { Total Isolations of } \\
\text { Gram-negutive } \\
\text { Organisms } \\
\text { Associated with } \\
\text { Sepsis }\end{array}$ & $\begin{array}{l}\text { Total Isolations of } \\
\text { Other Organisms } \\
\text { Associated with } \\
\text { Sepsis }\end{array}$ & $\begin{array}{l}\text { Total No. of } \\
\text { Organisms Isolated } \\
\text { Associated with } \\
\text { Sepsis }\end{array}$ & $\begin{array}{l}\text { Total No. } \\
\text { of } \\
\text { Admissions }\end{array}$ & $\begin{array}{l}\text { Sepsis } \\
\text { Rate (\%) }\end{array}$ \\
\hline 1 & $\left\{\begin{array}{l}3 \text { months before } \\
3 \text { months after }\end{array}\right.$ & $\begin{array}{r}14 \\
4\end{array}$ & $\begin{array}{l}7 \\
6\end{array}$ & $\begin{array}{r}4 \\
10\end{array}$ & $\begin{array}{l}25 \\
20\end{array}$ & $\begin{array}{l}184 \\
170\end{array}$ & $\begin{array}{l}14 \\
12\end{array}$ \\
\hline 2 & $\left\{\begin{array}{l}3 \text { months before } \\
3 \text { months after }\end{array}\right.$ & $\begin{array}{l}9 \\
1\end{array}$ & $\begin{array}{r}25 \\
1\end{array}$ & $\begin{array}{l}3 \\
0\end{array}$ & $\begin{array}{r}37 \\
2\end{array}$ & $\begin{array}{l}148 \\
170\end{array}$ & $\begin{array}{c}25 \\
1\end{array}$ \\
\hline 3 & $\left\{\begin{array}{l}3 \text { months before } \\
3 \text { months after }\end{array}\right.$ & $\begin{array}{l}7 \\
1\end{array}$ & $\begin{array}{l}9 \\
4\end{array}$ & $\begin{array}{l}4 \\
2\end{array}$ & $\begin{array}{r}20 \\
7\end{array}$ & $\begin{array}{l}132 \\
125\end{array}$ & $\begin{array}{r}15 \\
6\end{array}$ \\
\hline 4 & $\left\{\begin{array}{l}6 \text { months before } \\
6 \text { months after }\end{array}\right.$ & $\begin{array}{l}18 \\
16\end{array}$ & $\begin{array}{l}44 \\
19\end{array}$ & $\begin{array}{r}12 \\
4\end{array}$ & $\begin{array}{l}74 \\
39\end{array}$ & $\begin{array}{l}268 \\
291\end{array}$ & $\begin{array}{l}28 \\
13\end{array}$ \\
\hline 5 & $\left\{\begin{array}{l}6 \text { months before } \\
6 \text { months after }\end{array}\right.$ & $\begin{array}{l}18 \\
15\end{array}$ & $\begin{array}{l}44 \\
29\end{array}$ & $\begin{array}{l}8 \\
5\end{array}$ & $\begin{array}{l}70 \\
49\end{array}$ & $\begin{array}{l}296 \\
292\end{array}$ & $\begin{array}{l}24 \\
17\end{array}$ \\
\hline
\end{tabular}

Table I Time of infection related to closure

\begin{tabular}{|c|c|c|c|c|c|c|c|c|}
\hline Ward & $\begin{array}{l}\text { Period of Time in } \\
\text { Relation to Closure }\end{array}$ & $\begin{array}{l}\text { Total } \\
\text { Number }\end{array}$ & $\begin{array}{l}\text { Associated } \\
\text { with Sepsis }\end{array}$ & $\begin{array}{l}\text { Fully Sensitive or } \\
\text { Resistant to } \\
\text { Penicillin Only }\end{array}$ & $\begin{array}{l}\text { Resistant to } \\
\text { Two or More } \\
\text { Antibiotics }\end{array}$ & $\begin{array}{l}\text { Cloxacillin } \\
\text { Resistant }\end{array}$ & $\begin{array}{l}\text { Total No. } \\
\text { of } \\
\text { Admissions }\end{array}$ & $\begin{array}{l}\text { Staph. aureus } \\
\text { Sepsis Rate }(\%)\end{array}$ \\
\hline 1 & $\left\{\begin{array}{l}3 \text { months before } \\
3 \text { months after }\end{array}\right.$ & $\begin{array}{r}17 \\
4\end{array}$ & $\begin{array}{r}14 \\
4\end{array}$ & $\begin{array}{l}5 \\
4\end{array}$ & $\begin{array}{r}12 \\
0\end{array}$ & $\begin{array}{r}11 \\
0\end{array}$ & $\begin{array}{l}184 \\
170\end{array}$ & $\begin{array}{l}8 \\
2\end{array}$ \\
\hline 2 & $\begin{array}{l}3 \text { months before } \\
3 \text { months after }\end{array}$ & $\begin{array}{r}12 \\
1\end{array}$ & $\begin{array}{l}9 \\
1\end{array}$ & $\begin{array}{l}4 \\
1\end{array}$ & $\begin{array}{l}8 \\
0\end{array}$ & $\begin{array}{l}6 \\
0\end{array}$ & $\begin{array}{l}148 \\
170\end{array}$ & $\begin{array}{l}6 \\
0.6\end{array}$ \\
\hline 3 & $\begin{array}{l}3 \text { months before } \\
3 \text { months after }\end{array}$ & $\begin{array}{l}8 \\
1\end{array}$ & $\begin{array}{l}7 \\
1\end{array}$ & $\begin{array}{l}4 \\
1\end{array}$ & $\begin{array}{l}4 \\
0\end{array}$ & $\begin{array}{l}4 \\
0\end{array}$ & $\begin{array}{l}132 \\
125\end{array}$ & $\begin{array}{l}5 \\
0 \cdot 8\end{array}$ \\
\hline 4 & $\left\{\begin{array}{l}6 \text { months before } \\
6 \text { months after }\end{array}\right.$ & $\begin{array}{l}22 \\
17\end{array}$ & $\begin{array}{l}18 \\
16\end{array}$ & $\begin{array}{r}7 \\
13\end{array}$ & $\begin{array}{r}15 \\
4\end{array}$ & $\begin{array}{l}7 \\
1\end{array}$ & $\begin{array}{l}268 \\
291\end{array}$ & $\begin{array}{l}7 \\
5\end{array}$ \\
\hline 5 & $\left\{\begin{array}{l}6 \text { months before } \\
6 \text { months after }\end{array}\right.$ & $\begin{array}{l}19 \\
21\end{array}$ & $\begin{array}{l}18 \\
15\end{array}$ & $\begin{array}{r}13 \\
9\end{array}$ & $\begin{array}{r}6 \\
12\end{array}$ & $\begin{array}{l}5 \\
6\end{array}$ & $\begin{array}{l}296 \\
292\end{array}$ & $\begin{array}{l}6 \\
5\end{array}$ \\
\hline
\end{tabular}

Table II Isolations of Staph. aureus 
Eleven patients received systemic antimicrobial therapy as in each case the infection was considered to be serious.

\begin{tabular}{ll}
\hline Number of Patients Treated & Antimicrobial Therapy \\
\hline 2 & $\begin{array}{l}\text { fusidic acid + cloxacillin } \\
\text { (500 mg qds) } \\
\text { fusidic acid + lincomycin } \\
\text { fusidic acid alone } \\
\text { fusidic acid + trimethoprim/ }\end{array}$ \\
2 & $\begin{array}{l}\text { sulphamethoxazole } \\
\text { fusidic acid + gentamicin } \\
\text { chloramphenicol alone } \\
\text { chloramphenicol + novobiocin } \\
1\end{array}$ \\
$\mathbf{t r i m e t h o p r i m} /$ sulphamethoxazole alone \\
1 (1 died)
\end{tabular}

Apart from the six patients who died, the rest recovered though several needed extra surgery, such as drainage of pus, wound toiletry, etc, and, apart from one patient who died, all these patients remained in hospital for at least two weeks. Twentytwo patients remained in hospital for at least one month, and seven remained hospitalized for over three months with chronic wound infection, two of them being young patients who had undergone elective surgical operations.

\section{Discussion}

WARD 1

Following cleaning, the Staph. aureus sepsis rate fell from $8 \%$ to $2 \%$ (Table II). Moreover, in the three months after cleaning all Staph. aureus infections were caused by antibiotic-sensitive strains very different from the strain causing the epidemic before closure and of no consistent phage type, suggesting possible self-infection with the patient's own commensal strain.

The amount of infection caused by Gram-negative and other organisms remained much the same in the two periods, which is not surprising, as most of this sepsis was of the genital and urinary tract, and was probably caused by organisms derived from the patient's own vaginal, perineal, or bowel flora (Grüneberg, 1969).

\section{WARD 2}

As may be seen from Table I, there was a very marked reduction in sepsis rates from $25 \%$ to $1 \%$ following cleaning of the ward. Staph. aureus sepsis rate fell from $6 \%$ to $0.6 \%$ (Table II). Moreover, infections caused by 'hospital strains' of Staph. aureus, ie, multiple-resistant strains including those resistant to cloxacillin, were eliminated. Gramnegative infections were also greatly reduced.

WARD 3

The total sepsis rate fell from $15 \%$ to $6 \%$ following closure and cleaning of the ward (Table I). The Staph. aureus sepsis rate fell from 5 to $0.8 \%$ (Table II) with the elimination of infections caused by hospital strains of Staph. aureus (including cloxacillin-resistant strains). Gram-negative infections also were more than halved.

WARD 4

Total sepsis rate fell from 28 to $13 \%$ after closure and cleaning of the ward (Table I). The Staph. aureus sepsis rate was reduced from 7 to $5 \%$ (Table II), although the sepsis rate attributable to multiple antibiotic-resistant, ie, 'hospital', strains fell from 4 to $1 \%$. The number of infections caused by cloxacillin-resistant strains fell from seven to one in the two periods. The effects of cleaning would probably have been more striking had not at least two patients with 'resistant' Staph. aureus infections (including one with a cloxacillin-resistant strain) been readmitted to the re-opened ward before their infections had been eliminated.

\section{WARD 5}

The total sepsis rate fell from $24 \%$ in the six months before closure to $17 \%$ in the six months after closure (Table I), but the Staph. aureus sepsis rate fell only from 6 to $5 \%$ (Table II), although in the first three months following closure the rate had fallen from 6 to $4 \%$. The rate of sepsis caused by multipleantibiotic-resistant strains of Staph. aureus, ie, 'hospital strains', increased slightly from 1.7 to $2.4 \%$, while the number of isolations of cloxacillinresistant Staph. aureus increased from five to six. It is significant that the cloxacillin-resistant strains of Staph. aureus isolated before cleaning were all of similar phage type and that this was a phage type completely different from that of the strains isolated after re-opening the ward. Although cleaning the ward appeared to eliminate infection by one strain of cloxacillin-resistant Staph. aureus, another patient became infected with a cloxacillin-resistant Staph. aureus of a different phage type. As previously mentioned, this patient may have been infected in the operating theatre. Subsequently he was nursed on ward 5 for several months, during which time other patients on the ward became infected.

\section{Conclusions}

This study clearly shows that, after closing and cleaning wards in the manner described, outbreaks of sepsis caused by Staph. aureus stop. Although the wards all catered for the same categories of patients upon re-opening as they had done before closure, for several months after re-opening wards sepsis rates were reduced, especially sepsis caused by 'hospital 
strains' of Staph. aureus. The results on wards 4 and 5 were not as good as on the other three wards. In one instance two infected patients were readmitted before their infections had been eradicated. There was also failure to isolate effectively newly admitted patients who were, or who became, infected. Effective isolation of infected patients in the wards included in this study was extremely difficult through lack of suitable facilities.

Although closing and cleaning wards appears to reduce sepsis rates and end outbreaks of infection, it is not clear how this comes about. There may be more than one reason. There is little doubt that people carrying pathogens are a much more potent source of cross-infection than is the presence of organisms on walls and floors in wards (Williams, Blower, Shooter, and Garrod, 1966). The actual removal of patients from a ward and the detecting, treating, and isolating of carriers of epidemic organisms might well be more important than the actual washing down of a ward. There is no doubt that cleaning a ward has a psychological effect on staff working in it, for it is likely that nursing techniques will be carried out with more care on a clean ward where there is an increased awareness of risks of cross-infection and of sepsis in general.

Not all people who were infected with cloxacillinresistant strains of Staph. aureus became seriously ill, although there were five deaths at least partly attributable to them. Serious sepsis followed elective surgery in two young patients who were otherwise healthy. It is now generally accepted that cloxacillinresistant strains of Staph. aureus are capable of causing sepsis including serious sepsis (Colley, McNicol, and Bracken, 1965; Jensen and Lassen, 1969). The widespread and increasing use in hospitals of penicillins and cephalosporins is associated with an increase in the isolation of cloxacillin-resistant Staph. aureus both from septic lesions and carrier sites (Hale and Selkon, 1970; Parker and Hewitt, 1970).
If cloxacillin and related antibiotics are to remain effective for the treatment of staphylococcal sepsis, resistant strains must be controlled in hospitals. Emptying and thoroughly cleaning wards, coupled with the treatment of carriers and the isolation of infected patients as described, can be expected to get rid of such resistant strains from wards until and unless another infected patient or heavy disperser from a carrier site is admitted.

We would like to thank both Dr C. E. D. Taylor and Professor G. Dick for their invaluable help with the preparation of this paper. We would also like to thank Mr M. A. T. Coles and the laboratory staff for their technical work; the nursing and medical staff on the wards involved for their cooperation; and Dr M. T. Parker and the staff of the Cross Infection Reference Laboratory, Colindale, for their help with phage typing of staphylococci. Finally we must thank Mrs P. Hanrahan and Miss C. Esson for all their typing.

\section{References}

Colley, E. W., McNicol, M. W., and Bracken, P. M. (1965). Methicillin-resistant staphylococci in a general hospital. Lancet, 1, 595-597.

Grüneberg, R. N. (1969). Relationship of infecting urinary organism to the faecal flora in patients with symptomatic urinary infections. Lancet, 2, 766-768.

Hale, J. H., and Selkon, J. B. (1970). Multiply resistant staphylococci. Lancet, 2, 528-529.

Hewitt, J. H., and Parker, M. T. (1968). Sensitivity of penicillinaseforming strains of Staphylococcus aureus and of their penicillinase-negative variants to cephaloridine, cephalothin, methicillin and benzylpenicillin. J. clin. Path., 21, 75-84.

Jensen, K., and Lassen, H. C. A. (1969). Combined treatment with antibacterial chemotherapeutic agents in staphylococcal infections. Quart. J. Med., NS, 38, 91-106.

Noone, P., Griffiths, R. J., and Taylor, C. E. D. (1970). Hexachlorophane for treating carriers of Staphylococcus aureus. Lancet, 1, 1202-1203.

Parker, M. T., and Hewitt, J. H. (1970). Methicillin resistance in Staphylococcus aureus. Lancet, 1, 800-804.

Williams, R. E. O., Blowers, R., Garrod, L. P., and Shooter, R. A. (1966). Hospital Infection, 2nd ed. pp. 231-260. LloydLuke, London. 